JEL: C33, C55, Q18, Q58

Enoch Kwaw-Nimeson ${ }^{1}$, Ze Tian ${ }^{1,2}$

${ }^{1}$ Hohai University

${ }^{2}$ Low Carbon Economy Institute

China

\title{
THE IMPACT OF AGRICULTURAL PRODUCER PRICE ON SUSTAINABLE FOOD SECURITY IN AFRICA - A SYSTEM GMM APPROACH
}

Purpose. Given the efforts towards achieving the United Nations' Sustainable Development Goals (SDGs) for food security by 2030, this study investigates the moderating impact of public investments in agriculture on the agricultural producer price - agricultural sustainability nexus in 40 African countries covering the period from 2000 till 2019.

Methodology / approach. In this study we used multiple regression techniques to explore a dynamic panel data model based on the one-step system Generalized Method of Moments (SystemGMM). Proposed by Arellano and Bover and further developed by Blundell and Bond, the SystemGMM estimator was preferred over other techniques because of its efficiency in eliminating the simultaneous biases that are associated with regression model estimations. Specifically, the onestep System-GMM was preferred over the two-step System-GMM for our estimation due to the efficiency of its optimal weighting matrices.

Results. The study discovered that although the interactions between public investments on agriculture and agricultural sustainability amplify the positive impact of a set of explanatory variables on agricultural producer price to an extent, the impact on food security in Africa is insignificant. The study also discovers that the net effects of a set of interactive terms on producer price in the developing countries in Africa are slightly lower than in the least-developed countries. The weighted average food security index for the period under study was abysmal 44.54\%, indicating moderate food insecurity in Africa.

Originality / scientific novelty. In the context of food security literature in Africa, this study is the first attempt at exploring the agricultural producer price - agricultural sustainability nexus based on the moderating impact of public investments on agriculture with the Global Food Security Index (GFSI), a composite food security model developed by the Economist Intelligence Unit (EIU). Among our study proposals it is a call for a detour from the current agricultural investment and producer price policies especially the current 'one-size-fits-all' regional frameworks which have proved to be less progressive and less transformative to more robust country/sector-specific frameworks that have the potential to better the fortunes of agriculture and improve food security.

Practical value / implications. The current state of agricultural producer price in most African countries is ample proof that the role and importance of the producer price have been gravely diminished. Despite governments' efforts towards improving food security, the evidence as presented in this study supports the fact that those efforts have not achieved much success. The study, which contains a number of recommendations, highlights agricultural producer price as a potentially important driver of agricultural sustainability and sustainable food security in Africa.

Key words: agricultural producer price, food security, agricultural sustainability, public investments on agriculture, System-GMM. 


\section{Agricultural and Resource Economics: International Scientific E-Journal http://are-journal.com}

Introduction and review of literature. Goal 2 of the SDGs is targeted towards ending global hunger, unimpeded access to adequate food, sustainable agriculture, and food systems, increase in food productivity and income as well as achieving food security. According to the SDGs Report for 2020, $22.4 \%$ of the human population was affected by moderate to severe food insecurity in 2014, rising to $25.9 \%$ ( 2 billion people) in 2019 [1]. Besides the usual caveats that threaten food systems (climate, political conflicts, and pests crisis), the recent COVID-19 pandemic further worsened food systems all over the world, with up to 132 million more people suffering from undernourishment in 2020. In Sub-Saharan Africa, about $56.8 \%$ of the population suffered moderate to severe food insecurity in 2019. To ensure sustainable food security for the foreseeable future, it cannot be overemphasized the impact of public investments on agriculture, headlined by government expenditure, turned into the provision of multiple assistance especially to rural smallholder food producers, agricultural incentives and subsidies, development of rural infrastructure, training and development, etc. Furthermore, the latest upward trend of food insecurity, exacerbated largely by the COVID-19 pandemic which has rendered nearly 300 million people "acutely food-insecure" in 2020-2021 according to the World Food Program (WFP) [2] is indicative that the continual longstanding overdependence on public investments to agriculture as a driver of agricultural sustainability and food security especially in Africa may prove detrimental both in the short and long term. To this end, the participation of private investments is crucial and needful and can help strengthen domestic food markets, expand agricultural value chains, and give rise to new and innovative technologies to increase food productivity and efficiency.

Despite governments' efforts, the Food and Agriculture Organization (FAO) estimates that the share of central governments expenditure allocated to agriculture fluctuated around $1.6 \%$ between 2001 and 2017, with Asia \& the Pacific and Africa being the regions that received the highest percentage of the agriculture expenditure [3]. Taking into account that most African economies are agrarian, this meager share indicates large public underinvestment in agriculture which further leads to low food productivity and security. Though private investments and public-private partnership (PPP) contributions towards ending hunger and extreme poverty as well as ensuring food security are significant, OECD (2014) [4] estimates that for the global economy to meet the surging demand for food, agricultural productivity should increase by at least $60 \%$ over the next forty (40) years.

Public Investment in Agriculture and Agricultural Sustainability in Africa. The share of government total expenditure in agriculture compared with the agriculture sector's contribution to GDP fell from 0.42 in 2001 to 0.31 in 2015 and 0.28 in 2018 worldwide [1]. This signifies that for all the given years, governments' investment commitments towards agriculture were less than proportionate to contributions of agricultural sector to GDP. What does this continual fall in public investments mean for food producers? FAO (2020) [5] suggests that the drop in agricultural investments is mainly a result of a redirection of investments from agriculture to other sectors. We 


\section{Agricultural and Resource Economics: International Scientific E-Journal}

http://are-journal.com

investigated the impact of public investments in agriculture on agricultural producer price (hereafter "producer price") as well as the impact of the interactions between public investments on agriculture and agricultural sustainability on producer prices by testing the following hypotheses: Hypothesis 1 (H1): Public investment on agriculture is positively correlated to producer prices in Africa. Hypothesis 2 (H2): The interaction between public investments on agriculture and agricultural sustainability is positively correlated to producer prices in Africa.

Food Security and Public Investments in Agriculture in Africa. Research has been conducted extensively on a plethora of moderating factors that impact food security for which mixed outcomes have been reported. These studies have focused on the linkages to agricultural foreign direct investment (FDI) [6], food security risk assessment and forecast [7], global hunger [8], input subsidy [9], agricultural research and development (R\&D) investment [10], agricultural policies, productivity and environmental sustainability [11], agribusiness [12], irrigation [13] and many others. Furthermore, the issues relating specifically to food insecurity in Africa have resulted in numerous policy reforms at least over the last half-century. Balié and Narayanan [14] argue that the general focus of agricultural policy reforms in Africa must be on local market development which ultimately will increase agricultural output. One of such crucial policies was the promotion of the Green Revolution in Africa, driven by a technology revolution. It was a bundle of intensive irrigation, enhanced seeds, pesticides, and fertilizers with a focus on improving crop production, supported by significant public investment.

At the institutional level, FAO [3] used a recursive dynamic computable general equilibrium (CGE) model based on the multipurpose CGE model [15] to evaluate the role of public investments on agriculture in Nicaragua to assess the impact of public investments on economic growth and poverty reduction from 2010 to 2017. The report established that an increase of $0.5 \%$ or $1 \%$ of GDP from public investments on agriculture in the agriculture sector increases overall GDP growth between $0.8 \%$ and $3.5 \%$ annually through 2030 depending on the level of investments while reducing total rural poverty between $0.5 \%$ to $2.25 \%$ and extreme poverty by $0.16 \%$ to $0.31 \%$. Going by conventional understanding based on this finding, one would expect public investments in agriculture to increase food security more in developed countries than in developing and the least-developed countries. To test this thought in the Africa context, we developed this hypothesis: Hypothesis 3 (H3): Public investments in agriculture have a bigger impact on food security in developing countries than in the least developed countries in Africa.

The purpose of the article. The underlying objective of this study is to explore the moderating role and impact of African governments' public investments in agriculture on the agricultural producer price - agricultural sustainability nexus in 40 African countries between 2000 and 2019.

More specifically, in keeping with the global pledge towards achieving SDG2 for food security, we explore how these investments influenced by governments' policies towards producer prices allocated to smallholders and rural food producers 
have impacted agricultural sustainability and food security in Africa in the presence of a set of explanatory variables and country-control effects. In the context of the producer price literature, to the best of our knowledge, this study is the first to apply the global food security index as a measure of food security and also represents the first attempt at exploring the impact of public investment on agriculture on the producer prices - agricultural sustainability nexus in the context of achieving food security in Africa.

Materials and methods. Data and Sources. The datasets utilized in this study were obtained mainly from the Development Flows to Agriculture indicators of FAO and World Development Indicators (WDI) of the World Bank. We used Producer Price Index (PPI) as our dependent variable while Agriculture Orientation Index (AOI), Global Food Security Index (GFSI), Gross Crop Production Index (GCPI), LAND, Consumer Price Index (CPI), and Agricultural Gross Domestic Product (AGDP) were used as explanatory variables. Lastly, agricultural sector employment (Emp), household consumption expenditure (HCE), population (Pop), gross national income (GNI), and government final consumption expenditure (GFCE) were employed as country-control effects. Countries sampled in this study largely depended on the availability of data for the variables under consideration. Table 1 shows the list of developing and the least-developed countries used in the study.

Table 1

\section{Countries used in the Study}

\begin{tabular}{|c|c|}
\hline Developing Countries & The Least-Developed Countries \\
\hline $\begin{array}{l}\text { Algeria, Cape Verde, Cameroon, Cote } \\
\text { d'Ivoire, Egypt, Equatorial Guinea, } \\
\text { Ghana, Kenya, Mauritius, Morocco, } \\
\text { Namibia, Seychelles, South Africa, } \\
\text { Tunisia, Zimbabwe }\end{array}$ & $\begin{array}{l}\text { Angola, Benin, Burkina Faso, Burundi, Central African } \\
\text { Republic (CAR), Chad, Congo, Eritrea, Ethiopia, } \\
\text { Gambia, Guinea, Guinea Bissau, Madagascar, Malawi, } \\
\text { Mali, Mozambique, Niger, Rwanda, Senegal, Sierra } \\
\text { Leone, Tanzania, Togo, Zambia }\end{array}$ \\
\hline
\end{tabular}

Source: UNCTAD.

Model Specification. According to Magrini et al. [16], the producer price is a weighted average of three elements, namely, the lagged producer price deflated by the CPI; the lagged wholesale price deflated by the CPI; and a weighted average of the three components of the lagged real producer price, $P_{t-1}$. Based on an unbalanced panel data, we investigate the producer price - agricultural sustainability linkages to food security by estimate a model where producer price is dependent on the moderating impact of public investments on agriculture and other variables as well as several country-control effects. First, we state the general equation as:

$$
P P I_{i t}=f\left(E X P_{i t}, C O N T_{i t}\right) \text {, }
$$

where $P P_{i t}$ is a vector of producer prices legislated in any African country, $i$ at time, $t$;

$E X P_{i t}$ is a set of explanatory variables employed to measure their net effects on the dependent variable whiles $C O N T_{i t}$ measures the country-control effects on the dependent variable.

Following Ibrahim et al. [17], to test the validity of $H 1$ and $H 2$, we estimate this 
baseline model:

$$
P P I_{i t}=\gamma_{0} P P I_{i t-1}+\gamma_{1} E X P_{i t}+\gamma_{2} C O N T_{i t}+\eta_{i}+\delta_{t}+\Omega_{i t},
$$

Expanding equation 2 to incorporate their variable vectors allows us to specify the producer price model to capture the components of EXP $P_{i t}$ and $C O N T_{i t}$. The new expanded model is given in the form:

$$
\begin{aligned}
& P P I_{i t}=\gamma_{0} P P I_{i t-1}+\gamma_{1} A I O_{i t}+\gamma_{2} G F S I_{i t}+\gamma_{3} G C P I_{i t}+\gamma_{4} L A N D_{i t}+\gamma_{5} C P I_{i t}+ \\
& \gamma_{6} A G D P_{i t}+\gamma_{7} E m p_{i t}+\gamma_{8} H C E_{i t}+\gamma_{9} P o p_{i t}+\gamma_{10} G N I_{i t}+\gamma_{11} G F C E_{i t}+\eta_{i}+\delta_{t}+ \\
& \Omega_{i t},
\end{aligned}
$$

where $P P I_{i t-1}$ measures the convergence effect from lagged PPI. We added a one-year lag to the dependent variable to permit flexibility while PPI reacts to lagged PPI [18]. $\gamma_{1}-\gamma_{11}$ are a set of interest variables to be estimated while $\eta_{i}, \delta_{t}$, and $\Omega_{i t}$ account for overlooked country-control effects, time effects, and the idiosyncratic error term respectively. GFSI $i t$ is used as our preferred composite indicator to measure food security. The GFSI is a dynamic qualitative and quantitative benchmark model constructed from 59 unique indicators that measure the drivers of food security across both developing and developed countries [19].

Public Investments on Agriculture, Agricultural Sustainability, and Producer Prices. In order to test $H I$ and $H 2$, we assessed the impact of public investments on agriculture and agricultural sustainability on producer prices. We began by suggesting that agricultural sustainability may not have an independent impact on producer prices and although there is an emergence of a plethora of methodologies and tools, there is still no consensus on agricultural sustainability assessment methodologies, measurement tools, or standards [20]. We, therefore, measured agricultural sustainability effects through food productivity. To do this, we constructed an interactive term between public investments in agriculture and food productivity $(A O I \times G C P I)$ and then incorporated this new term into the baseline model. Equation 2 was thus reconstructed as:

$$
P P_{i t}=\alpha_{0} P P_{i t-1}+\alpha_{1} E X P_{i t}+\alpha_{2} C O N T_{i t}+\delta\left(A O I_{i t} \times G C P I_{i t}\right) \eta_{i}+\delta_{t}+\Omega_{i t}
$$

From equation 4 , while $\alpha_{1}$ measures the direct impact of the explanatory variables on producer prices, $\delta$ measures the impact of the interactive term effects on producer prices. We expect our findings to align with studies which report that agricultural investments ceteris paribus augment agricultural productivity [21] and in effect result in producer price spillovers [22].

Furthermore, we investigated the net impact of the interactive term on the explanatory variables for producer price. Specifically, to ascertain the validity of $H 2$, we explored the individual impact of each of the explanatory variables on producer price as moderated by the interactive term. To capture the individual effects, we estimated equation 5 as follows:

$$
\frac{\partial P P_{i t}}{\partial E X P_{i t}}=\alpha_{1}+\delta(A O I \times G C P I)_{i t}
$$

Additionally, we matched the interactive term against each of the explanatory variables beside $A O I$ and GCPI to evaluate the net effects of each explanatory variable on producer price. 


\section{Agricultural and Resource Economics: International Scientific E-Journal}

http://are-journal.com

Food Security in Developing and the Least-Developed Countries. To test the validity of $H 3$, we specified a model that incorporated the interactive terms between the variables that measure human development index (GNI per capita) and food security (GFSI) to measure the net effects of public investment in agriculture on producer prices in both developing and least-developing countries in Africa. To capture this, we followed a similar undertaking by Sabir et al. [23] who studied the impact of FDI in developed and developing countries. However, instead of constructing specific development dummies for developing and the least-developed countries, we investigated the development effects on producer prices and food security through HDI. We accordingly constructed these two separate interactive terms $D C(G F S I \times G N I)$, and $L D C(G F S I \times G N I)$. The coefficients of these two interactive terms allowed us to compare different effects of producer prices on food security in Africa depending on the level of development.

Incorporating these two interactive terms, we estimate the development effects models in equations 6 and 7 as follows:

Developing Countries:

$$
P P_{i t}=\alpha_{0} P P_{i t-1}+\alpha_{1} E X P_{i t}+\alpha_{2} C O N T_{i t}+\vartheta D C(G N I \times G F S I)_{i t}+\eta_{i}+\delta_{t}+\Omega_{i t}
$$

Least-Developed Countries:

$$
P P_{i t}=\alpha_{0} P P_{i t-1}+\alpha_{1} E X P_{i t}+\alpha_{2} C O N T_{i t}+\rho L D C(G N I \times G F S I)_{i t}+\eta_{i}+\delta_{t}+\Omega_{i t},
$$

where $\vartheta D C(G N I \times G F S I)_{i t}$ and $\rho L D C(G N I \times G F S I)_{i t}$ measure the net development effects of producer prices on a set of explanatory and country-control effects in $i$ developing and least-developed countries respectively at time $t$.

Model Estimation. To estimate appropriate models to investigate the relationship between producer prices and our sets of explanatory variables and country-control effects, the choice of methodology and measurement may vastly influence outcomes and interpretations. There is the possibility that estimating our baseline model (equation 3) could result in some simultaneous biases which then would render the coefficient estimators inefficient. Firstly, from the model, we make an exogeneity assumption between the producer price and the explanatory variables as well as a probable bidirectional causality from the explanatory variables to producer price and vice-versa. Secondly, we anticipate that the model may suffer from correlation between the country-control effects and the explanatory variables as well as autocorrelation as the past values of the explanatory variables are expected to have a significant impact on the present values. To address these issues, we employed the dynamic panel data model based on the System-GMM approach proposed by Arellano and Bover [24] and further developed by Blundell and Bond [25]. Specifically, we specified the one-step System-GMM estimator which can account for both difference and level equations by incorporating the lagged differences of the regressors as instruments. The one-step System-GMM was preferred over the twostep GMM as it is more efficient due to its optimal weighting matrices. Furthermore, the System-GMM estimator with a small cross-section dimension could lead to 
estimating parameters prone to bias and a weakened over-identification test [26]. Roodman [27] estimates that this is due to instrument proliferation which can be solved by reducing the dimensionality of the instrumental variable matrix. To avoid this problem, we employed a cross-sectional dataset of countries $(\mathrm{N})=40$ and years $(\mathrm{T})=20$ where we limited the instrument lag on the dependent variable to one. To ensure the consistency of the test results, we specified the Arellano and Bond [28] post-estimation test to test for serial autocorrelation among the instruments. The guiding principle here is that for the instruments to be valid and the model to be correctly specified, the null hypothesis (AR (1)) of no autocorrelation must be rejected if prob. $<0.05$ in favor of the alternative hypothesis AR (2) if prob. > 0.05 and vice-versa. Then we specified the Hansen test to check instrument overidentification [29].

Results and discussion. Descriptive Statistics. The descriptive statistics of the panel data estimates are presented in Table 2 below.

Table 2

\section{Descriptive Statistics}

\begin{tabular}{|l|c|c|c|}
\hline \multicolumn{1}{|c|}{ Variables } & Mean & S.D. & Obs \\
\hline PPI & 413.67 & 6880.53 & 692 \\
\hline AOI & 0.54 & 1.32 & 759 \\
\hline GFSI & 44.54 & 8.11 & 361 \\
\hline GCPI & 112.24 & 29.04 & 680 \\
\hline LAND & 45.59 & 21.51 & 680 \\
\hline CPI & 104.00 & 47.73 & 728 \\
\hline AGDP & 21.57 & 13.46 & 772 \\
\hline Emp & 51.66 & 22.67 & 780 \\
\hline HCE & 71.18 & 15.63 & 752 \\
\hline Pop & 2.42 & 0.92 & 792 \\
\hline GNI & 4.55 & 4.70 & 650 \\
\hline GFCE & 14.71 & 6.07 & 752 \\
\hline
\end{tabular}

Source: authors' calculations.

Impact of Public Investments in Agriculture on Producer Prices, and Agricultural Sustainability. To ascertain the impact of public investments on agriculture on producer prices and agricultural sustainability in Africa, we explored the interactive term $(A O I \times G C P I)$ in equation 4 and measured their net impact on producer prices. Additionally, we matched the interactive term against each of the explanatory variables beside $A O I$ and $G C P I$ to evaluate their net effects on producer price. A similar approach was adopted by Dwumfour and Ntow-Gyamfi [30] for a different study. Results are presented in Table 3 below.

Impact of Producer Prices on Food Security in Developing and the LeastDeveloped Countries. To measure the effects separately, we reconstructed two different unbalanced panel datasets, one for developing countries and another for the least-developed countries. We employed a cross-sectional dataset of the developing countries, $(\mathrm{N})=17$ and years $(\mathrm{T})=8$ and a cross-sectional dataset of the leastdeveloped countries, $(\mathrm{N})=23$ and years $(\mathrm{T})=10$. 
Table 3

Public Investments to Agriculture, Producer Prices and Agricultural Sustainability (Dependent Variable: Lagged PPI)

\begin{tabular}{|c|c|c|c|c|c|c|}
\hline Variable & [1] & [2] & [3] & [4] & [5] & [6] \\
\hline Lagged PPI & $\begin{array}{c}0.309 * * * \\
(5.22)\end{array}$ & $\begin{array}{l}0.51 * * * \\
(8.62)\end{array}$ & $\begin{array}{c}0.642 * * * \\
(3.05)\end{array}$ & $\begin{array}{c}1.181 * * * \\
(3.87)\end{array}$ & $\begin{array}{c}1.029 * * * \\
(4.72)\end{array}$ & $\begin{array}{c}0.805^{* * *} * \\
(3.42)\end{array}$ \\
\hline AOI & $\begin{array}{c}1.742^{* *} \\
(2.04)\end{array}$ & & & & & \\
\hline $\mathrm{AO} 1 \times \mathrm{GCPI}$ & & $\begin{array}{l}1.402 \\
(0.89)\end{array}$ & & & & \\
\hline GFSI & & & $\begin{array}{c}0.447 * * * \\
(1.05)\end{array}$ & & & \\
\hline \multicolumn{2}{|c|}{ GFSI $\times$ AO $1 \times$ GCPI } & & $\begin{array}{c}-1.953 * * * \\
(-0.16)\end{array}$ & & & \\
\hline LAND & & & & $\begin{array}{l}-0.111 \\
(-0.56)\end{array}$ & & \\
\hline \multicolumn{2}{|c|}{$\mathrm{LAND} \times \mathrm{AO} 1 \times \mathrm{GCPI}$} & & & $\begin{array}{l}-0.879 \\
(-0.76)\end{array}$ & & \\
\hline CPI & & & & & $\begin{array}{l}0.129 \\
(1.31)\end{array}$ & \\
\hline \multicolumn{2}{|c|}{$\mathrm{CPI} \times \mathrm{AO} 1 \times \mathrm{GCPI}$} & & & & $\begin{array}{l}-0.162 \\
(-0.87)\end{array}$ & \\
\hline AGDP & & & & & & $\begin{array}{l}0.100 \\
(1.43)\end{array}$ \\
\hline \multicolumn{2}{|c|}{$\mathrm{AGDP} \times \mathrm{AO} 1 \times \mathrm{GCPI}$} & & & & & $\begin{array}{l}-0.064 \\
(-0.60)\end{array}$ \\
\hline Emp & $\begin{array}{l}0.027 \\
(0.26)\end{array}$ & $\begin{array}{l}-0.053 \\
(-0.42)\end{array}$ & $\begin{array}{l}0.012 \\
(0.36)\end{array}$ & $\begin{array}{l}0.034 \\
(0.42)\end{array}$ & $\begin{array}{l}0.009 \\
(0.29)\end{array}$ & $\begin{array}{l}-0.019 \\
(-0.52)\end{array}$ \\
\hline $\mathrm{HCE}$ & $\begin{array}{l}0.049 \\
(0.50) \\
\end{array}$ & $\begin{array}{l}-0.067 \\
(-0.64) \\
\end{array}$ & $\begin{array}{l}0.036 \\
(1.48) \\
\end{array}$ & $\begin{array}{l}-0.005 \\
(-0.07) \\
\end{array}$ & $\begin{array}{l}0.043 \\
(2.37) \\
\end{array}$ & $\begin{array}{l}0.023 \\
(1.06) \\
\end{array}$ \\
\hline Pop & $\begin{array}{l}-0.005 \\
(-0.04) \\
\end{array}$ & $\begin{array}{l}0.010 \\
(0.09)\end{array}$ & $\begin{array}{l}-0.021 \\
(-0.93)\end{array}$ & $\begin{array}{l}-0.048 \\
(-0.46)\end{array}$ & $\begin{array}{l}0.029 \\
(1.47)\end{array}$ & $\begin{array}{l}0.022 \\
(1.16)\end{array}$ \\
\hline GNI & $\begin{array}{l}0.008 \\
(0.16)\end{array}$ & $\begin{array}{l}-0.011 \\
(-0.22) \\
\end{array}$ & $\begin{array}{l}-0.024 \\
(-0.61)\end{array}$ & $\begin{array}{l}-0.062 \\
(-1.40) \\
\end{array}$ & $\begin{array}{l}-0.036 \\
(-0.87) \\
\end{array}$ & $\begin{array}{l}-0.022 \\
(-0.61) \\
\end{array}$ \\
\hline GFCE & $\begin{array}{l}-0.067 \\
(-1.03)\end{array}$ & $\begin{array}{c}0.081 \\
(-1.30)\end{array}$ & $\begin{array}{l}-0.035 \\
(-1.22)\end{array}$ & $\begin{array}{l}0.263 \\
(0.65)\end{array}$ & $\begin{array}{l}-0.021 \\
(-0.76)\end{array}$ & $\begin{array}{l}-0.042 \\
(-1.56)\end{array}$ \\
\hline Observations & 760 & 760 & 760 & 760 & 760 & 760 \\
\hline Instruments & 31 & 31 & 31 & 31 & 31 & 31 \\
\hline Time Dummy & YES & YES & YES & YES & YES & YES \\
\hline AR (1) & 0.000 & 0.001 & 0.001 & 0.000 & 0.000 & 0.001 \\
\hline AR (2) & 0.053 & 0.172 & 0.212 & 0.182 & 0.241 & 0.214 \\
\hline Hansen Test & 0.076 & 0.071 & 0.056 & 0.125 & 0.070 & 0.019 \\
\hline
\end{tabular}

Note: The coefficients are one-step System-GMM estimates with lagged PPI treated as predetermined whiles the T-statistics are in parentheses. All instruments matrices are "collapsed".

AR (1) and AR (2) report the Arellano - Bond p-values for the first and second-order autocorrelation of the first-differenced residuals.

Levels of significance are represented as $* * *=\mathrm{p}<0.01 ; * * \mathrm{p}<0.05 ;$ and $* \mathrm{p}<0.1$.

Source: authors' calculations. 


\section{Agricultural and Resource Economics: International Scientific E-Journal}

http://are-journal.com

Since $\mathrm{N}$ needs to be greater than $\mathrm{T}$, we decided to measure the effects from 2012 to 2019 for the developing countries and 2010 to 2019 for the least-developed countries, thereby fulfilling the $\mathrm{N}>\mathrm{T}$ condition for using the System-GMM approach for the estimation.

By computing equations 5 and 6 , we were able to explore our two interactive terms: $D C(G F S I \times G N I)$ and $L D C(G F S I \times G N I)$ to capture the effects. By this approach, we were able to identify the direction of correlation between the producer price and that of the interactive term. Additionally, we matched the interactive terms against each of the explanatory variables beside GNI and GFSI to evaluate their net effects on producer price in both developing and the least-developed countries. Columns [7] to [12] and [13] to [18] present the results for developing and the leastdeveloping countries respectively. Tables 4 and 5 below present the results of the interactions.

Robustness Check. To confirm the robustness of our results, an additional test was conducted. Here, we removed public investments in agriculture variable from equation 3 to capture the new effect on producer prices and agricultural sustainability. There are several factors responsible for the low public investment on agriculture. The discussion concerning the general role agricultural investments play on agricultural sustainability and food security has received mixed reviews. By removing the public investment on agriculture variable from the instrument set while controlling for each of the other explanatory variables, we found the results to be consistent with the baseline model results in Table 3.

Hypotheses Testing. Hypothesis 1: In column [1], we tested the validity of $\mathrm{HI}$ and found that producer price was positively correlated to public investments on agriculture. Per this finding, we affirm the validity and acceptance of $H 1$, that an increase in public investments on agriculture increases producer prices ceteris paribus. However, as it has already been stated, the share of public expenditure on agriculture is lower in Africa than in any other region in the world. According to the 2020 World Food and Agriculture report, Africa received $42 \%$ of all investment flows to agriculture, forestry, and fishing in 2018, a bumper increase from the $23 \%$ it received in 2000 [31]. Furthermore, Africa from 2000 to 2018 led all other regions in the share of agriculture, forestry, and fishing value-added in total GDP at an average of $15.07 \%$. Comparatively, agricultural GDP in Asia (8.09\%), Oceania (3.2\%), the Americas $(1.81 \%)$, and Europe $(1.67 \%)$ evidently was much lower than in Africa but that notwithstanding, the share of gross agricultural income and producer prices to smallholders and food producers in Africa is much lower than in other regions. Usually, in Africa, low producer prices are as a result of low farm yields, exchange rate volatility, corrupt marketing practices, hostile price legislation, and general microeconomic policy volatility. This study asserts that for any meaningful increases to producer prices to occur, Africa governments' commitment to public investments on agriculture must substantially increase in addition to finding solutions to the problems stated above. 
Agricultural and Resource Economics: International Scientific E-Journal http://are-journal.com

Table 4

Public Investments on Agriculture, Producer Prices and Food Security in Developing Countries (Dependent Variable: Lagged PPI)

\begin{tabular}{|c|c|c|c|c|c|c|}
\hline Variable & [7] & [8] & [9] & [10] & [11] & [12] \\
\hline \multicolumn{7}{|c|}{ Developing Countries } \\
\hline Lagged PPI & $\begin{array}{c}0.361 * * \\
(2.83)\end{array}$ & $\begin{array}{c}0.331 * * \\
(2.51)\end{array}$ & $\begin{array}{c}0.272 * * \\
(2.01)\end{array}$ & $\begin{array}{c}0.296 * * \\
(2.34)\end{array}$ & $\begin{array}{c}0.278 * * \\
(2.16)\end{array}$ & $\begin{array}{c}0.262 * * * \\
(1.89)\end{array}$ \\
\hline GFSI $\times$ GNI & $\begin{array}{l}-0.018 \\
(-0.14)\end{array}$ & & & & & \\
\hline AOI & & $\begin{array}{c}1.002 * * * \\
(6.23)\end{array}$ & & & & \\
\hline \multicolumn{2}{|c|}{$\mathrm{AOI} \times \mathrm{GFSI} \times \mathrm{GNI}$} & $\begin{array}{l}0.067 \\
(0.63)\end{array}$ & & & & \\
\hline GCPI & & & $\begin{array}{c}0.335 * * * \\
(3.39)\end{array}$ & & & \\
\hline \multicolumn{2}{|c|}{$\mathrm{GCPI} \times \mathrm{GFSI} \times \mathrm{GNI}$} & & $\begin{array}{l}0.101 \\
(1.10)\end{array}$ & & & \\
\hline LAND & & & & $\begin{array}{c}0.703 * * * \\
(3.08)\end{array}$ & & \\
\hline \multicolumn{2}{|c|}{ LAND $\times$ GFSI $\times$ GNI } & & & $\begin{array}{l}0.038 \\
(0.35) \\
\end{array}$ & & \\
\hline CPI & & & & & $\begin{array}{l}0.049 \\
(0.24)\end{array}$ & \\
\hline \multicolumn{2}{|c|}{$\mathrm{CPI} \times \mathrm{GFSI} \times \mathrm{GNI}$} & & & & $\begin{array}{l}-0.192 \\
(-1.11) \\
\end{array}$ & \\
\hline AGDP & & & & & & $\begin{array}{l}0.408 \\
(1.73)\end{array}$ \\
\hline \multicolumn{2}{|c|}{ AGDP $\times$ GFSI $\times$ GNI } & & & & & $\begin{array}{l}0.281 \\
(1.30)\end{array}$ \\
\hline Emp & $\begin{array}{l}-0.260 \\
(-1.28) \\
\end{array}$ & $\begin{array}{c}-0.164 * \\
(-1.93) \\
\end{array}$ & $\begin{array}{c}-0.159 * * \\
(-2.53) \\
\end{array}$ & $\begin{array}{c}-0.183 * * \\
(-3.02)\end{array}$ & $\begin{array}{c}-0.140 * * \\
(-2.39) \\
\end{array}$ & $\begin{array}{l}-0.177 \\
(-1.43) \\
\end{array}$ \\
\hline $\mathrm{HCE}$ & $\begin{array}{l}-0.088 \\
(-0.42)\end{array}$ & $\begin{array}{l}0.046 \\
(0.54)\end{array}$ & $\begin{array}{l}0.027 \\
(0.44)\end{array}$ & $\begin{array}{l}0.0127 \\
(0.17)\end{array}$ & $\begin{array}{c}0.0489 \\
(0.65)\end{array}$ & $\begin{array}{l}-0.208 \\
(-1.23)\end{array}$ \\
\hline Pop & $\begin{array}{l}0.134 \\
(0.62)\end{array}$ & $\begin{array}{l}0.192 \\
(2.52)\end{array}$ & $\begin{array}{c}0.146 * * \\
(2.20)\end{array}$ & $\begin{array}{c}0.136 * * \\
(2.47)\end{array}$ & $\begin{array}{c}0.165 * * \\
(2.45)\end{array}$ & $\begin{array}{l}0.259 \\
(3.46)\end{array}$ \\
\hline GFCE & $\begin{array}{l}-0.038 \\
(-0.25)\end{array}$ & $\begin{array}{l}-0.079 \\
(-1.17)\end{array}$ & $\begin{array}{l}-0.009 \\
(-0.14)\end{array}$ & $\begin{array}{l}-0.078 \\
(-1.63)\end{array}$ & $\begin{array}{l}-0.036 \\
(-0.41)\end{array}$ & $\begin{array}{l}-0.111 \\
(-0.99)\end{array}$ \\
\hline Observations & 119 & 119 & 119 & 119 & 119 & 119 \\
\hline Instruments & 12 & 12 & 12 & 12 & 12 & 12 \\
\hline Time Dummy & YES & YES & YES & YES & YES & YES \\
\hline AR (1) & 0.001 & 0.001 & 0.001 & 0.000 & 0.000 & 0.000 \\
\hline AR (2) & 0.211 & 0.554 & 0.153 & 0.154 & 0.253 & 0.099 \\
\hline Hansen Test & 0.032 & 0.050 & 0.055 & 0.071 & 0.015 & 0.026 \\
\hline
\end{tabular}

Source: authors' calculations. 
Table 5

Public Investments on Agriculture, Producer Prices and Food Security in the Least-Developed Countries (Dependent Variable: Lagged PPI)

\begin{tabular}{|c|c|c|c|c|c|c|}
\hline Variable & [13] & [14] & [15] & [16] & [17] & [18] \\
\hline \multicolumn{7}{|c|}{ The Least-Developing Countries } \\
\hline Lagged PPI & $\begin{array}{c}0.403 * \\
(3.02)\end{array}$ & $\begin{array}{l}0.391 * \\
(6.66)\end{array}$ & $\begin{array}{c}0.380 * * * \\
(5.01)\end{array}$ & $\begin{array}{c}0.407 * * * \\
(5.40)\end{array}$ & $\begin{array}{c}0.434 * * * \\
(6.26)\end{array}$ & $\begin{array}{c}0.442 * * * \\
(4.99)\end{array}$ \\
\hline GFSI $\times$ GNI & $\begin{array}{l}0.016 \\
(0.10)\end{array}$ & & & & & \\
\hline AOI & & $\begin{array}{c}1.688^{* * * *} \\
(6.70)\end{array}$ & & & & \\
\hline $\mathrm{AOI} \times \mathrm{GFSI} \times \mathrm{GNI}$ & & $\begin{array}{l}-0.082 \\
(-0.68)\end{array}$ & & & & \\
\hline GCPI & & & $\begin{array}{c}0.372 * * * \\
(4.66)\end{array}$ & & & \\
\hline \multicolumn{2}{|l|}{ GCPI $\times$ GFSI $\times$ GNI } & & $\begin{array}{l}-0.067 \\
(-0.47)\end{array}$ & & & \\
\hline LAND & & & & $\begin{array}{c}0.900 * * * \\
(7.23)\end{array}$ & & \\
\hline \multicolumn{2}{|l|}{ LAND $\times$ GFSI $\times$ GNI } & & & $\begin{array}{l}-0.045 \\
(-0.33)\end{array}$ & & \\
\hline CPI & & & & & $\begin{array}{l}-0.399 \\
(-0.42)\end{array}$ & \\
\hline \multicolumn{2}{|l|}{$\mathrm{CPI} \times \mathrm{GFSI} \times \mathrm{GNI}$} & & & & $\begin{array}{l}-0.140 \\
(-0.78)\end{array}$ & \\
\hline AGDP & & & & & & $\begin{array}{l}0.446 \\
(1.77)\end{array}$ \\
\hline \multicolumn{2}{|l|}{ AGDP $\times$ GFSI $\times$ GNI } & & & & & $\begin{array}{l}0.412 \\
(0.17)\end{array}$ \\
\hline Emp & $\begin{array}{l}-0.968 \\
(-1.76)\end{array}$ & $\begin{array}{l}0.168 \\
(2.15)\end{array}$ & $\begin{array}{l}0.033 \\
(0.57)\end{array}$ & $\begin{array}{l}-0.041 \\
(-0.64)\end{array}$ & $\begin{array}{l}0.053 \\
(0.90)\end{array}$ & $\begin{array}{l}0.006 \\
(0.06)\end{array}$ \\
\hline $\mathrm{HCE}$ & $\begin{array}{l}0.145 \\
(0.78)\end{array}$ & $\begin{array}{l}0.144 \\
(2.52)\end{array}$ & $\begin{array}{l}0.116 \\
(2.54)\end{array}$ & $\begin{array}{l}0.046 \\
(1.01)\end{array}$ & $\begin{array}{l}0.094 \\
(1.92)\end{array}$ & $\begin{array}{l}0.072 \\
(1.13)\end{array}$ \\
\hline Pop & $\begin{array}{l}0.496 \\
(1.43)\end{array}$ & $\begin{array}{l}-0.058 \\
(-0.98)\end{array}$ & $\begin{array}{l}0.043 \\
(1.00)\end{array}$ & $\begin{array}{l}0.166 \\
(2.94)\end{array}$ & $\begin{array}{l}0.063 \\
(1.38)\end{array}$ & $\begin{array}{l}-0.020 \\
(-0.17)\end{array}$ \\
\hline GFCE & $\begin{array}{l}-0.060 \\
(-0.39)\end{array}$ & $\begin{array}{l}0.984 \\
(2.00)\end{array}$ & $\begin{array}{l}0.001 \\
(0.02)\end{array}$ & $\begin{array}{l}-0.010 \\
(-0.13)\end{array}$ & $\begin{array}{l}0.009 \\
(0.14)\end{array}$ & $\begin{array}{l}-0.018 \\
(-0.25)\end{array}$ \\
\hline Observations & 207 & 207 & 207 & 207 & 207 & 207 \\
\hline Instruments & 16 & 16 & 16 & 16 & 16 & 16 \\
\hline Time Model & YES & YES & YES & YES & YES & YES \\
\hline AR (1) & 0.001 & 0.000 & 0.000 & 0.000 & 0.000 & 0.000 \\
\hline AR (2) & 0.554 & 0.972 & 0.628 & 0.577 & 0.798 & 0.942 \\
\hline Hansen Test & 0.350 & 0.057 & 0.010 & 0.017 & 0.003 & 0.011 \\
\hline
\end{tabular}

Source: authors' calculations.

Hypothesis 2: In column [2], by testing the validity of $H 2$, we found that producer price was negatively correlated and statistically insignificant to the coefficient of the interactive term $(A O I \times G C P I)$. We, therefore, fail to accept $\mathrm{H} 2$ 
since the interaction between public investments on agriculture, and agricultural sustainability does not increase producer prices in Africa, thereby suggesting a zerosum impact from the previous year's public investment in agriculture on the current year's producer price. This result is consistent with the result of the country-control effects where we found that the interaction between public investment on agriculture and food productivity also negatively impacted household consumption expenditure, gross national income per capita, and government final consumption expenditure. This result explains the high levels of inflation in most African countries, marked by a high consumer price index, resulting in households having to spend more in the current period than they did in the previous period to maintain the same standard of living. Based on our findings, about $71.2 \%$ of household incomes from agriculture in Africa are spent, and since household consumption expenditure is a key indicator for assessing household welfare, we estimate that low producer prices will further restrain the food producer' capacity to invest in additional farmlands, explore new seed and farming technologies, as well as employ other meaningful inputs that can increase food productivity.

Hypothesis 3: From our results, producer price was found to be negatively correlated and statistically insignificant to both the interactive term (GFSI $\times G N I)$ and their composite interactive term $(A O I \times G F S I \times G N I)$, indicating that the interaction between public investment on agriculture, food security index, and gross national income per capita has a negative relationship with producer prices in both developing and the least-developed countries. By this result, we fail to accept $H 3$ that public expenditures on agriculture have a bigger impact on food security in the developing countries than in the least-developed countries. This finding is consistent with those contained in reports by FAO [4] and United Nations [1]. In fact, from the results, the coefficients of both the interactive and composite interactive terms in the developing countries are slightly lower than in the least-developed countries, indicating that the rate of food insecurity worsened at a slightly higher rate in the developing countries than in the under-developed countries in Africa. This can be explained by the fact that the rate of economic growth in the least-developed countries has been less slow than in the developing countries as a result of structural economic transformation sponsored by the SDGs [32].

Lately, studies concerning attaining SDGs for food security in Africa have received considerable attention. Some of these studies have focused on food security linkages to public expenditure on agriculture [33], social inclusion and innovation [34], poverty eradication [35], agricultural diversification [36], and many others. The current study along with its findings adds to the food security literature by highlighting producer price as a potentially important driver of sustainable food security in Africa towards attaining the SDGs by 2030 . The study additionally makes the following contributions to the literature.

Firstly, we provide compelling evidence that although public investments in agriculture under the right conditions augment the producer price - agricultural sustainability nexus by amplifying the positive impact of a set of explanatory 


\section{Agricultural and Resource Economics: International Scientific E-Journal}

http://are-journal.com

variables on producer prices to an extent, public investments' impact on the studied nexus and food security are insignificant. This indicates that although public investments in agriculture exert positive effects on producer prices and agricultural sustainability, those effects are not reflected in food security in Africa. Secondly, this study makes a novel contribution to the literature by providing a comparative analysis of the net effects of the interactions between public investments in agriculture and agricultural sustainability on producer prices in the developing countries (DCs) and the least-developed countries (LDCs) in Africa by employing the global food security index as a composite indicator for food security in Africa. Lastly, we discovered that by controlling for the interactive terms, the coefficients of producer price were negatively correlated to the coefficients of the interactive terms in both developing and the least-developed countries. We also discovered that the coefficients of the composite interactive terms and the development effects were slightly lower in the developing countries than in the least-developed countries.

Conclusions. The current state of agricultural producer price in most African countries is ample proof that the role and importance of the producer price have been gravely diminished. Despite governments' efforts towards improving food security, the evidence as presented in this study supports the fact that those efforts have not achieved much success. Food insecurity in Africa is projected to rise because food quantities and quality availability are increasingly becoming disproportionate to population growth rates. This calls for strategic policies to increase food production.

From our findings, since public investments on agriculture augments producer prices which further impacts positively on food security in the long term, it would be prudent for African governments to consider policy changes that increase the overall investment commitments to agriculture. The study makes the following recommendations/proposals which we believe could ensure sustainable food security both in the short term and ultimately towards achieving agenda 2030.

Firstly, we believe that Africa can rebound onto the path towards sustainable food security by 2030 by detouring from the current "regional-to-country-driven" agricultural investment approaches to "country-to-regional-driven" approaches which, we believe, could be more practical, more progressive, and more transformative. This is because the indices of food insecurity in one African country widely differ from another and the current 'one-size-fits-all' agenda has proven to be less fruitful. For instance, Somalia through its Integrated Food Security Phase Classification (IPC) project is one of such nationalistic approaches adopted by their Food Security and Nutrition Analysis Unit (FSNAU) to provide "evidence-based analysis of Somali food, nutrition and livelihood security to facilitate both short-term emergency responses and long-term strategic planning to promote food and livelihood security for Somali people". The project currently in its 6th phase has chalked remarkable success including the provision of timely and relevant food security, nutrition and livelihood analyses for emergency response and the provision of technical support for Somali institutions and allied partners in food security, assessment and analyses. 


\section{Agricultural and Resource Economics: International Scientific E-Journal}

http://are-journal.com

Secondly, the current regional food security programs have proven not to be robust enough to efficiently address the specific country-by-country food insecurity challenges as managed by regional food security frameworks. Specifically, the Comprehensive Africa Agriculture Development Program (CAADP) by the New Partnership for Africa's Development (NEPAD), the most influential agriculture-led integrated framework in Africa if revised to accommodate this recommendation could potentially lead to lowering food insecurity in Africa. In view of the vicious impact of the COVID-19 pandemic which has further threatened food systems and caused a $60 \%$ increase in acute food insecurity across Africa, the CAADP's Implementation Strategy and Roadmap (IS\&R) which targets farmer organizations, the private sector, developmental partners, civil societies, and Regional Economic Communities (RECs) towards achieving the 2025 Vision on CAADP's objective of agricultural transformation and sustainable inclusive growth has the potential to lower food insecurity in the short-term in the worst hit 'acutely food-insecure' countries like D.R. Congo, Niger, Mali, Sudan, and Burkina Faso.

Thirdly, the time has come for African governments to begin to embrace agricultural diversification beyond public investments to adequately address the challenges associated with the avoidable loss of food as it is being transported from farms to markets or trading centers as a crucial measure to combat food insecurity in Africa. Increases in incomes of food producers automatically increase their capacity to invest in more efficient storage and transportation systems which will actually reduce food loss. The International Conference on the West African Food Security Storage System by the Regional Agency for Agriculture and Food (RAAF) of the Economic Community of West African States (ECOWAS) held from 28th April to 10th May 2021 aimed at discussing/finding solutions to issues relating but not limited to food reserves and management of cyclical food crises in West Africa, the role of food reserves in the building of the resilience and social protection of households and partnerships and innovative financing mechanisms and the strengthening of the resilience of the Regional Food Storage System and its effective response capacity to the complexities of food crises.

Lastly, based on the findings of this study, we engage governments across Africa to consider a comprehensive overhaul of the age-old producer price policy frameworks to reflect current global trends ensuring fairness in the prices paid to food producers. Currently, most markets in Africa are poorly integrated and so new policies that especially target effective risk management mechanisms will potentially protect food producers against price shocks as well as production and market risks.

Data limitations are a bane to testing of a range of hypotheses. Based on the findings in this study, we encourage further studies into the challenges associated with the poor producer price transmissions from urban to rural economies and the probable impact of robust food security modeling and measurements on future food security policies and frameworks in the African context.

\section{Reference}

1. United Nations (2020), The Sustainable Development Goals Report 2020. 


\section{Agricultural and Resource Economics: International Scientific E-Journal}

http://are-journal.com

United Nations, New York, NY, USA, available at:
https://sdgs.un.org/publications/sustainable-development-goals-report-2020-24686.

2. World Bank (2021), Brief: Food Security and Covid-19, available at: https://www.worldbank.org/en/topic/agriculture/brief/food-security-and-covid-19.

3. FAO (2020), The contribution of public investment in the agricultural sector to economic growth and rural poverty reduction: a high-level dialogue in Nicaragua based on a prospective analysis. FAO, Rome, Italy, available at: www.fao.org/3/ca9467en/CA9467EN.pdf.

4. OECD (2014), Private investment to boost agricultural production and foster food security: policy framework for investment in agriculture. OECD. Paris, France. https://doi.org/10.1787/9789264212725-en.

5. FAO (2020), Statistical Yearbook - World Food and Agriculture 2020. Food and agriculture organization of the united nations. FAO, Rome, Italy. https://doi.org/10.4060/cb1329en.

6. Yao, H., Alhussam, M. I., Risha, O. A. and Memon, B. A. (2020), Analyzing the relationship between agricultural FDI and food security: evidence from belt and road countries. Sustainability, vol. 12, no. 7, pp. 1-20. https://doi.org/10.3390/su12072906.

7. Voronenko, I., Skrypnyk, A., Klymenko, N., Zherlitsyn, D. and Starychenko, Y. (2020), Food security risk in Ukraine: assessment and forecast. Agricultural and Resource Economics, vol. 6, no. 4, pp.63-75. https://doi.org/10.51599/are.2020.06.04.04.

8. Mason-D'Croz, D., $\quad$ Sulser, T. B., Wiebe, K., $\quad$ Rosegrant, M. W., Lowder, S. K., Nin-Pratt, A., Willenbockel, D., Robinson, S., Zhu, T., Cenacchi, N., Dunston, S. and Robertson, R. D. (2019), Agricultural investments and hunger in Africa modeling potential contributions to SDG2 - Zero Hunger. World Development, vol. 116, pp. 38-53. https://doi.org/10.1016/j.worlddev.2018.12.006.

9. Fan, S., Gulati, A. and Thorat, S. (2008), Investment, Subsidies, and Pro-poor Growth in Rural India. Agricultural Economics, vol. 39, no. 2, pp. 163-170. https://doi.org/10.1111/j.1574-0862.2008.00328.x.

10. Lee, J., Koh, M. and Jeong, G. (2017), Analysis of the Impact of Agricultural R\&D Investment on Food Security. Applied Economic Letters, vol. 24, no. 1, pp. 49-53. https://doi.org/10.1080/13504851.2016.1161708.

11. Lankoski, J. and Thiem, A. (2020), Linkages between agricultural policies, productivity and environmental sustainability. Ecological Economics, vol. 178, no. 106809, pp. 1-9. https://doi.org/10.1016/j.ecolecon.2020.106809.

12. van Westen, A. C. M., Magnus, E., Wangu, J. and Worku, S. E. (2019), Inclusive agribusiness models in the Global South: the impact on local food security. Current Opinion in Environmental Sustainability, vol.41, no.4, pp.64-68. https://doi.org/10.1016/j.cosust.2019.11.003.

13. Domenech, L. (2015), Improving irrigation access to combat food insecurity and under nutrition: a review. Global Food Security, vol. 6, no. 10, pp. 24-33. https://doi.org/10.1016/j.gfs.2015.09.001. 


\section{Agricultural and Resource Economics: International Scientific E-Journal}

http://are-journal.com

14. Balié, J. and Narayanan, B. (2019), What should be the focus of agricultural policy reforms in Sub-Saharan Africa? A CGE analysis. Margin - The Journal of Applied Economic Research, vol. 13, no. 4, pp. 401-435. https://doi.org/10.1177/0973801019868392.

15. Cicowiez, M. and Lofgren, H. (2017), A GEM for streamlined dynamic CGE analysis: structure, interface, data and macro application. World Bank Policy Research Working Paper 8272. Washington, D.C., USA.

16. Magrini, E., Balié, J. and Morales-Opazo, C. (2017), Price signals and supply responses for staple food crops in Sub-Saharan Africa. Applied Economic Perspectives and Polisy, vol. 40, is. 2, pp. 276-296. https://doi.org/10.1093/aepp/ppx037.

17. Ibrahim, M., Ibrahim, O. A. and Sare, Y. A. (2019), Networking for foreign direct investment in Africa: how important are ICT environment and financial sector development? Journal of Economic Integration, vol. 34, no. 2, pp. 346-369. https://doi.org/10.11130/jei.2019.34.2.346.

18. Bevan, A., Estrin, S. and Meyer, K. (2004), Foreign investment location and institutional development in transition economies. International Business Review, vol. 13, no. 1, pp. 43-64. https://doi.org/10.1016/j.ibusrev.2003.05.005.

19. Economic Intelligence Unit (2020), The Global Food Security Index, available at: https://foodsecurityindex.eiu.com.

20. Lampridi, M. G., Sørensen, C. G. and Bochtis, D. (2019), Agricultural sustainability: a review of concepts and methods. Sustainability, vol. 11, no. 18, pp. 1-27. https://doi.org/10.3390/su11185120.

21. Zidouemba, P. R. and Gerard, F. (2017), Does agricultural productivity actually matter for food security in a landlocked Sub-Saharan African country? The case of Burkina Faso. Canadian Journal of Agricultural Economics, vol. 66, no. 1, pp. 103-142. https://doi.org/10.1111/cjag.12140.

22. Guo, J. and Tanaka, T. (2020), Dynamic transmissions and volatility spillovers between global price and U.S. producer price in agricultural markets. Journal of Risk and Financial Management, vol.13, no. 4, pp.1-20. https://doi.org/10.3390/jrfm13040083.

23. Sabir, S., Anum, R. and Kamran, A. (2019), Institutions and FDI: evidence from developed and developing countries. Financial Innovation, vol. 5, no. 8, pp. 120. https://doi.org/10.1186/s40854-019-0123-7.

24. Arellano, M. and Bover, O. (1995), Another look at the instrumental variable estimation of error-components models. Journal of Econometrics, vol. 68, no. 1, pp. 29-51. https://doi.org/10.1016/0304-4076(94)01642-D.

25. Blundell, R. and Bond, S. R. (1998), Initial conditions and moment restrictions in dynamic panel data models. Journal of Econometrics, vol. 87, no. 1, pp. 115-143. https://doi.org/10.1016/S0304-4076(98)00009-8.

26. Bowsher, C. G. (2002), On testing over identifying restrictions in dynamic panel data models. Economics Letters, vol. 77, no. 2, pp. 211-220. https://doi.org/10.1016/S0165-1765(02)00130-1.

27. Roodman, D. (2009), How to do xtabond2: an introduction to difference and 
system GMM in Stata. Stata Journal, vol. 9, no. 1, pp. 86-136. https://doi.org/10.1177/1536867X0900900106.

28. Arellano, M. and Bond, S. (1991), Some tests of specification for panel data: Monte Carlo evidence and an application to employment equations. Review of Economic Studies, vol. 58, no. 2, pp. 277-297. https://doi.org/10.2307/2297968.

29. Hansen, L. P. (1982), Large sample properties of generalized method of moments estimators. Econometrica, vol. 50, no. 4, pp. 1029-1054. https://doi.org/10.2307/1912775.

30. Dwumfour, R. A. and Ntow-Gyamfi, M. (2018), Natural resources, financial development and institutional quality in Africa: is there a resource curse? Resources Policy, vol. 59, no. 7, pp. 411-426. https://doi.org/10.1016/j.resourpol.2018.08.012.

31. FAO (2020), Regional overview of food security and nutrition in Africa containing the damage of economic slowdowns and downturns to food insecurity in Africa. FAO, Rome, Italy.

32. UNCTAD (2019), The Least Developed Countries Report 2019. United Nations: New York, NY, USA, available at: https://unctad.org/webflyer/leastdeveloped-countries-report-2019.

33. Matchaya, G. C. (2020), Public spending on agriculture in Southern Africa: sectoral and intra-sectoral impact and policy implications. Journal of Policy Modeling, vol. 42, no. 6, pp. 1228-1247. https://doi.org/10.1016/j.jpolmod.2020.05.002.

34. Anser, M. K., Godil, D., Aderounmu, B. and Onabote, A. (2021), Social inclusion, innovation and food security in West Africa. Sustainability, vol. 13, no. 1, pp. 1-12. https://doi.org/10.3390/su13052619.

35. Gassner, A., Harris, D. and Mausch, K. (2019), Poverty eradication and food security through agriculture in Africa: rethinking objectives and entry points. Outlook on Agriculture, vol. 48, no. 4, pp. 309-315. https://doi.org/10.1177/0030727019888513.

36. Waha, K., van Wijk, M. T., Fritz, S., See, L., Thornton, P. K., Wichern, J. and Herrero, M. (2018), Agricultural diversification as an important strategy for achieving food security in Africa. Global Change Biology, vol. 24, no. 8, pp. 33903400. https://doi.org/10.1111/gcb.14158.

\section{Citation:}

Стиль-ДСТУ:

Kwaw-Nimeson E., Tian Z. The impact of agricultural producer price on sustainable food security in Africa - a system GMM approach. Agricultural and Resource Economics. 2021. Vol. 7. No. 3. Pp. 60-76. https://doi.org/10.51599/are.2021.07.03.04.

Style-APA:

Kwaw-Nimeson, E. and Tian, Z. (2021), The impact of agricultural producer price on sustainable food security in Africa - a system GMM approach. Agricultural and Resource Economics, vol. 7, no. 3, pp. 60-76. https://doi.org/10.51599/are.2021.07.03.04. 